\title{
Pertumbuhan dan Hasil Kacang Hijau (Vigna radiata, L.) pada Beberapa Dosis Pupuk Organik dan Kerapatan Tanam
}

\author{
Mungbean Growth and Yield on Different Organic Fertilizer Dosage and Planting Density
}

\section{Desi Putri Hastuti, Supriyono*, Sri Hartati}

Program Studi Agroteknologi, Fakultas Pertanian, Universitas Sebelas Maret

Corresponding author: supriyono59@staff.uns.ac.id

\begin{abstract}
Mungbean is one of the strategic annual food crops that needed by Indonesian people because of the high protein and minerals. Production of mungbean in Indonesia always decreases. Cultural improvements are needed to increase productivity i.e by appropriate fertilization and plant density. The experiment objective was to find out the optimum dosage of organic fertilizer and plant density for the growth and yield of mungbean. The experiment was carried out using factorial completely randomized design (CRD). The first factor treatments were organic fertilizer which consisted of 0, 5, 10, 15, and 20 ton $\mathrm{ha}^{-1}$, while the second-factor treatments were planted density which consisted of 1 and 2 plants in the hole. Organic fertilizer of 5 ton $h^{-1}$ gave the best result for plant height, number of branches, flowering age, number of pods, fresh weight and dried straw, weight of 100 seeds, number and weight of seeds, small of seeds number and P nutrient uptake of the plant. The 2 plants per hole gave the best result for branches number, pods number and number of small seeds. Application of 5 ton hal organic fertilizer and 1 plant per hole gave better yield. No interaction of organic fertilizer and plant density to mungbean growth and yield.
\end{abstract}

Keywords: mungbean yield, organic fertilizer, plant density, $P$ uptake, vegetative growth

Cite this as: Hastuti, D. P., Supriyono, \& Hartati, S. 2018. Pertumbuhan dan Hasil Kacang Hijau (Vigna radiata, L.) pada Beberapa Dosis Pupuk Organik dan Kerapatan Tanam. Caraka Tani: Journal of Sustainable Agriculture. 33(2), 89-95. doi: http://dx.doi.org/10.20961/carakatani.v33i2.20412

\section{PENDAHULUAN}

Kacang hijau merupakan salah satu tanaman pangan sumber protein nabati. Kandungan protein kacang hijau sebesar $22 \%$ menempati urutan ketiga setelah kedelai dan kacang tanah (Purwono dan Hartono, 2005). Kacang hijau berumur genjah (55-65 hari), tahan kekeringan, variasi jenis penyakit relatif sedikit, dapat ditanam pada lahan kurang subur dan harga jual relatif tinggi serta stabil. Berdasarkan data Badan Pusat Statistik (2015), produksi kacang hijau di Indonesia mengalami penurunan dari 341.342 ton tahun $^{-1}$ menjadi 271.463 ton tahun $^{-1}$ (tahun 2011 dibanding 2015). Berbagai faktor menyebabkan penurunan produksi kacang hijau, antara lain kesuburan tanah rendah, alih fungsi lahan, faktor iklim tidak mendukung, dan praktik budidaya tidak tepat. Upaya peningkatan produktivitas kacang hijau dapat dilakukan dengan memperbaiki efisiensi pemupukan dan jumlah tanaman per lubang tanam. Pupuk organik mempunyai peran penting dalam memperbaiki sifat fisik, kimia, dan biologi tanah. Pupuk organik dapat menggemburkan tanah, memacu aktivitas mikroorganisme tanah dan membantu pengangkutan unsur hara ke dalam akar tanaman, meskipun ketersediaan unsur hara essensial (makro dan mikro) relatif lebih rendah daripada pupuk anorganik (Suwahyono, 2011). Sumber

\footnotetext{
* Received for publication April 17, 2018

Accepted after corrections August 30, 2018
} 
pupuk organik antara lain pupuk kandang, pupuk hijau, dan kompos. Penggunaan pupuk kandang berupa kotoran (ayam dan sapi) dapat meningkatkan kandungan $\mathrm{P}$ tersedia dalam tanah sebesar 65,7\% (Hossain et al., 2016). Unsur P menjadi penting bagi kacang hijau karena kemampuannya bersimbiosis dengan Rhizobium untuk mengubah $\mathrm{N}$ bebas dari udara menjadi $\mathrm{N}$ tersedia bagi tanaman.

Ahmad et al., (2004) menyatakan kerapatan tanaman sangat mempengaruhi pertumbuhan dan hasil biji. Jumlah tanaman per lubang dapat digunakan untuk meningkatkan efisiensi penggunaan faktor lingkungan bagi tanaman. Kompetisi intraspesifik tanaman dapat terjadi akibat populasi tinggi karena jarak tanam rapat (Jahan dan Hamid, 2004). Penelitian bertujuan untuk menentukan dosis pupuk organik dan jumlah tanaman per lubang optimal bagi pertumbuhan dan hasil kacang hijau.

\section{METODE PENELITIAN}

Penelitian dilaksanakan pada bulan Oktober Desember 2017 di lahan percobaan Fakultas Pertanian, Universitas Sebelas Maret, Jumantono, Karanganyar. Lokasi penelitian terletak pada koordinat $7^{\circ} 37^{\prime} 48,3^{\prime \prime}$ LS dan $110^{\circ} 56^{\prime} 51,2^{\prime \prime}$ BT dengan ketinggian tempat $170 \mathrm{~m}$ di atas permukaan laut. Tanah yang digunakan adalah tanah alfisol yang memiliki kandungan hara rendah sehingga termasuk dalam tanah marginal. Pelaksanaan penelitian meliputi pengolahan tanah minimal menggunakan cangkul, penyediaan benih kacang hijau varietas VIMA-1, penanaman dengan jarak tanam 40x20 cm, pemberian pupuk organik dan anorganik (pupuk urea, SP-36 dan $\mathrm{KCl})$ dilakukan pada awal penanaman dengan cara dibenamkan di sekeliling lubang tanam. Pemeliharaan meliputi penyiraman, penjarangan, penyiangan, penanggulangan hama serta panen. Pengamatan pertumbuhan vegetatif melalui pengukuran tinggi tanaman, berat kering brangkasan melalui pengovenan selama $2 \times 24$ jam pada suhu $70{ }^{\circ} \mathrm{C}$. Pengamatan generatif melalui waktu muncul bunga, jumlah polong, berat 100 biji, jumlah dan berat biji per tanaman.

Kondisi lingkungan penelitian homogen sehingga dirancang dengan metode Rancangan Acak Lengkap (RAL) faktorial dengan tiga ulangan. Faktor pertama berupa dosis pupuk organik $0,5,10,15,20$ ton ha ${ }^{-1}$, dan faktor kedua berupa jumlah tanaman per lubang (1 dan 2), sehingga terdapat 30 satuan percobaan.

Variabel yang diamati meliputi tinggi tanaman, jumlah cabang produktif, umur berbunga, jumlah polong, bobot segar brangkasan, bobot kering brangkasan (ditimbang setelah dioven $70{ }^{\circ} \mathrm{C}$ sehingga bobotnya konstan), berat 100 biji, jumlah biji per lobang tanam, berat biji per lobang tanam, jumlah biji kecil per lobang tanam dan serapan hara $\mathrm{P}$ tanaman. Hasil diukur berdasarkan berat biji yang dihasilkan setiap lubang tanam. Serapan hara $\mathrm{P}$ diukur pada fase vegetatif maksimum dengan metode Olsen melalui hasil perkalian $\mathrm{P}$ jaringan tanaman dengan berat kering tanaman.

Data dianalisis statistik dengan menggunakan analisis keragaman dan dilanjutkan Uji Jarak Berganda Duncan (DMRT) pada taraf kepercayaan $95 \%$ untuk mengetahui beda nyata antar perlakuan.

\section{HASIL DAN PEMBAHASAN}

Uraian tentang kandungan pupuk organik yang digunakan disajikan pada Table 1. Pupuk organik yang dimaksud merupakan pupuk organik yang diproduksi oleh Laboratorium Lapangan Universitas Sebelas Maret di Jatikuwung.

Table 1. Specification of utilized organic fertilizer

\begin{tabular}{clcc}
\hline No. & \multicolumn{1}{c}{ Sifat Kimia Pupuk } & Hasil & Satuan \\
\hline 1. & $\mathrm{pH}$ & $8,70^{*}$ & - \\
2. & C-Organik & $19,90^{*}$ & $\%$ \\
3. & $\mathrm{~N}$ Total & $1,72^{*}$ & $\%$ \\
4. & $\mathrm{P}_{2} \mathrm{O}_{5}$ & $2,10^{*}$ & $\%$ \\
5. & $\mathrm{~K}_{2} \mathrm{O}$ & $1,52^{*}$ & $\%$ \\
6. & $\mathrm{C} / \mathrm{N}$ & $11,57^{*}$ & - \\
\hline
\end{tabular}

\footnotetext{
* Sudah sesuai dengan Peraturan Menteri Pertanian No.70/Permentan/SR.140/10/2011 tentang standar pupuk organik padat
} 
Berdasarkan Table 2. terlihat bahwa tinggi tanaman pada dosis pupuk organik sebesar 10 ton $\mathrm{ha}^{-1}$ adalah tertinggi $(18,53 \mathrm{~cm})$, dan tidak berbeda nyata dibandingkan dengan dosis pupuk 5 ton ha ${ }^{-1}$ $(17,75 \mathrm{~cm})$. Pemberian dosis pupuk organik sebesar 5 ton ha $^{-1}$ mampu meningkatkan tinggi tanaman sebesar 55,32\% dibandingkan dengan kontrol (tanpa dosis pupuk). Peningkatan tinggi tanaman dipengaruhi oleh ketersediaan unsur NPK yang sejalan dengan meningkatnya dosis pupuk organik yang diberikan (Susanti et al., 2008). Figure 1. menunjukkan bahwa pertumbuhan tanaman lebih lambat terjadi pemberian pupuk organik (P1T1 dan P1T2). Pupuk organik memperbaiki kondisi tanah seperti menggemburkan tanah serta menyediakan unsur hara bagi pertumbuhan tanaman. Menurut Kresnatita et al. (2013), kondisi tanah yang baik

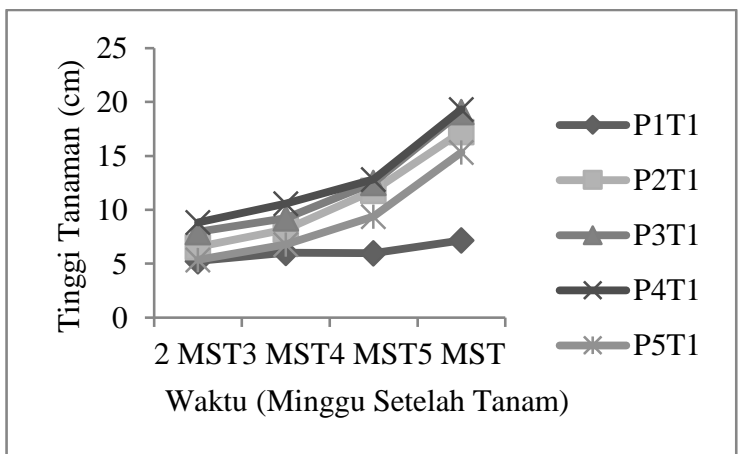

(a) akan menciptakan lingkungan tumbuh yang sesuai bagi pertumbuhan tanaman.

Kacang hijau diberi pupuk organik dosis 10 ton ha ${ }^{-1}$ tinggi tanaman mencapai tertinggi $(18,53$ $\mathrm{cm})$, namun tidak berbeda nyata dengan dosis 5 ton $\mathrm{ha}^{-1}(17,75 \mathrm{~cm})$. Peningkatan tinggi tanaman dipengaruhi oleh ketersediaan unsur NPK sejalan dengan peningkatan dosis pupuk organik (Susanti et al., 2008). Tinggi tanaman sebagai indikator pertumbuhan menunjukkan bahwa tanaman tidak diberi pupuk organik pertumbuhan lebih lambat (Figure 1). Pupuk organik memperbaiki kondisi tanah sehingga mampu menyediakan unsur hara bagi pertumbuhan tanaman. Menurut Kresnatita et al. (2013), kondisi tanah yang baik akan menciptakan lingkungan tumbuh yang sesuai bagi pertumbuhan tanaman.

Figure 1. (a) Plant height of Mungbean on different organic fertilizer dosage with 1 plant per hole. (b) Plant height of Mungbean on different organic fertilizer dosage with 2 plant per hole.

Keterangan : $\mathrm{P}=$ dosis pupuk, $\mathrm{T}=$ jumlah tanaman per lubang tanam, MST = minggu setelah tanam

Jumlah cabang produktif tertinggi tampak pada dosis pupuk organik 10 ton ha- ${ }^{-1}(17,83)$ tidak berbeda nyata dengan dosis 5 ton ha $^{-1}(13,33)$ (Table 2). Choudhary et al. (2011) menyatakan bahwa pemberian pupuk organik dengan dosis 0,85 ton ha $^{-1}$ yang dikombinasi dengan $50 \%$ dosis pupuk anorganik meningkatkan ketersediaan nitrogen dan fosfor sehingga mempengaruhi pembentukan cabang tanaman. Jumlah cabang produktif pada kerapatan 2 tanaman per lubang $33,6 \%$ lebih tinggi dibandingkan kerapatan 1 tanaman per lubang tanam (Table 3). Menurut Melati et al. (2008), populasi tanaman rendah tidak mendorong perbaikan pertumbuhan tanaman dengan persaingan antar tanaman berkurang.
Pupuk organik menstimulasi percepatan fase pembungaan tanaman. Fase berbunga pada tanaman diberi pupuk organik adalah 35 hari setelah tanam (HST), sedangkan tanpa pemberian pupuk organik adalah 37 HST. Fosfor berperan penting dalam proses metabolisme termasuk mempercepat proses pembungaan (Hidayat, 2008).

Berat segar brangkasan dipengaruhi oleh kandungan air pada sel-sel tanaman. Berat segar brangkasan tertinggi tampak pada dosis pupuk organik 10 ton ha ${ }^{-1}$ (20,97 gram per lubang tanam) dan tidak beda nyata dengan dosis pupuk 5 ton ha${ }^{1}$ (19,19 gram per lubang tanam). Rachmadhani et al. (2014) menyatakan bahwa perlakuan taraf pemupukan organik tidak menyebabkan perbedaan penyerapan air dan penimbunan hasil 
fotosintesis. Berat kering brangkasan tertinggi tampak pada dosis pupuk organik 20 ton ha ${ }^{-1}(8,72$ gram per lubang tanam) yang tidak berbeda nyata dengan dosis pupuk 5 ton $\mathrm{ha}^{-1}$ (6,74 gram per lubang tanam). Semakin tinggi berat kering brangkasan menunjukkan bahwa proses fotosintesis berjalan baik. Berat brangkasan segar dan kering tertinggi berbeda karena kandungan air dalam tumbuhan sehingga berat kering brangkasan pada dosis 20 ton ha ${ }^{-1}$ lebih tinggi. Menurut Hardjoloekito (2009), berat kering tanaman tergantung dari laju respirasi dan laju fotosintesis serta unsur hara yang diserap tanaman.

Table 2. Effect of organic fertilizer dosage on mungbean fosfat absorbtion, growth and yield

\begin{tabular}{lrrrrr}
\hline \multirow{2}{*}{\multicolumn{1}{c}{ Variabel pengamatan }} & \multicolumn{5}{c}{ Perlakuan dosis pupuk organik (ton ha h $^{-1}$} \\
\cline { 2 - 6 } & \multicolumn{1}{c}{0} & \multicolumn{1}{c}{10} & \multicolumn{1}{c}{15} & \multicolumn{1}{c}{20} \\
\hline Tinggi tanaman (cm) & $7,93^{\mathrm{a}}$ & $17,75^{\mathrm{b}}$ & $18,53^{\mathrm{b}}$ & $17,93^{\mathrm{b}}$ & $15,28^{\mathrm{b}}$ \\
Jumlah cabang produktif (cabang) & $4^{\mathrm{a}}$ & $13,33^{\mathrm{b}}$ & $17,83^{\mathrm{b}}$ & $14,83^{\mathrm{b}}$ & $13,83^{\mathrm{b}}$ \\
Umur berbunga (hari) & $36,67^{\mathrm{b}}$ & $35^{\mathrm{a}}$ & $35^{\mathrm{a}}$ & $35^{\mathrm{a}}$ & $35^{\mathrm{a}}$ \\
Berat segar brangkasan (g/tanaman) & $1,65^{\mathrm{a}}$ & $19,19^{\mathrm{b}}$ & $20,97^{\mathrm{b}}$ & $22,70^{\mathrm{b}}$ & $22,92^{\mathrm{b}}$ \\
Berat kering brangkasan (g/tanaman) & $0,89^{\mathrm{a}}$ & $6,74^{\mathrm{b}}$ & $7,44^{\mathrm{b}}$ & $7,66^{\mathrm{b}}$ & $8,72^{\mathrm{b}}$ \\
Jumlah polong (polong) & $6,67^{\mathrm{a}}$ & $35,50^{\mathrm{b}}$ & $37^{\mathrm{b}}$ & $39^{\mathrm{b}}$ & $42^{\mathrm{b}}$ \\
Berat 100 biji (g) & $4,67^{\mathrm{a}}$ & $5,52^{\mathrm{b}}$ & $5,23^{\mathrm{ab}}$ & $5,71^{\mathrm{b}}$ & $5,25^{\mathrm{ab}}$ \\
Jumlah biji normal(butir) & $58,50^{\mathrm{a}}$ & $271^{\mathrm{b}}$ & $316^{\mathrm{b}}$ & $266^{\mathrm{b}}$ & $313^{\mathrm{b}}$ \\
Berat biji (g/tanaman) & $2,66^{\mathrm{a}}$ & $13,59^{\mathrm{b}}$ & $14,10^{\mathrm{b}}$ & $13,77^{\mathrm{b}}$ & $14,48^{\mathrm{b}}$ \\
Jumlah biji kecil (butir) & $7,17^{\mathrm{a}}$ & $42,83^{\mathrm{a}}$ & $30,33^{\mathrm{a}}$ & $34,50^{\mathrm{a}}$ & $35,83^{\mathrm{a}}$ \\
Serapan hara P tanaman (g/tanaman) & $0,20^{\mathrm{a}}$ & $3,26^{\mathrm{b}}$ & $3,01^{\mathrm{b}}$ & $3,93^{\mathrm{b}}$ & $4,34^{\mathrm{b}}$ \\
\hline Kenang
\end{tabular}

Keterangan: Angka dalam baris sama diikuti huruf sama menunjukkan tidak berbeda nyata pada taraf kepercayaan 95\% menurut uji DMRT.

Table 3. Effect of number plant per hole on number of productive branch, pod and small seed

\begin{tabular}{lcc}
\hline \multirow{2}{*}{ Variabel pengamatan } & \multicolumn{2}{c}{ Perlakuan jumlah tanaman per lubang tanam } \\
\cline { 2 - 3 } & 1 & 2 \\
\hline Jumlah cabang produktif & $10,93^{\mathrm{a}}$ & $14,60^{\mathrm{b}}$ \\
Jumlah polong & $27,87^{\mathrm{a}}$ & $36,20^{\mathrm{b}}$ \\
Jumlah biji kecil & $23^{\mathrm{a}}$ & $37,27^{\mathrm{a}}$ \\
\hline
\end{tabular}

Keterangan: Angka pada baris sama diikuti huruf yang sama menunjukkan tidak berbeda nyata pada taraf kepercayaan 95\% menurut uji DMRT.

Jumlah polong kacang hijau pada dosis pupuk organik 20 ton $\mathrm{ha}^{-1}$ adalah tertinggi (42) tidak berbeda nyata dengan dosis pupuk 5 ton ha ${ }^{-1}$ $(35,50)$. Pengelolaan pemupukan merupakan komponen penting dalam budidaya yang berpengaruh terhadap pertumbuhan, perkembangan dan hasil kacang hijau (Asaduzzaman et al., 2008). Berdasarkan Table 3. terlihat bahwa kerapatan 2 tanaman per lubang tanam menghasilkan polong nyata lebih banyak 29,8\% dibandingkan kerapatan 1 tanaman per lubang tanam. Menurut Bunyamin dan Awaluddin (2013), makin tinggi populasi tanaman, sampai batas tertentu masih meningkatkan hasil.
Jumlah biji kacang hijau tergantung pada jumlah polong yang dihasilkan, namun tidak semua polong menghasilkan biji penuh karena faktor lingkungan. Jumlah biji tertinggi terlihat pada dosis pupuk organik 10 ton $\mathrm{ha}^{-1}$ yang tidak berbeda nyata dengan perlakuan dosis pupuk organik 5,15 dan 20 ton ha ${ }^{-1}$. Tanpa pupuk organik memberikan jumlah biji terendah (Table 2.). Pemberian pupuk organik meningkatkan ketersediaan unsur hara yang dibutuhkan dalam pembentukan biji. Bahan organik dalam kompos, pupuk kandang, pupuk hijau dan residu tanaman dapat menyediakan nutrisi bagi pertumbuhan dan hasil panen, serapan hara, kualitas biji serta kesuburan tanah (Shukla dan Tyagi, 2009). 
Berat 100 biji berhubungan dengan kualitas biji yang dihasilkan tanaman. Berat 100 biji yang diberi pupuk organik dengan dosis 15 ton ha ${ }^{-1}$ adalah tertinggi (5,70 gram) yang tidak berbeda nyata terhadap dosis pupuk organik 5 ton ha $^{-1}$ (5,52 gram). Tanpa pupuk organik menghasilkan berat 100 biji terendah (4,67 gram). Berat 100 biji dipengaruhi oleh ketersediaan hara dan kemampuan tanaman menyerap, misal fosfor dalam fase pengisian biji. Fosfor merupakan komponen penting penyusun senyawa untuk transfer energi (ATP dan nukleoprotein lain), untuk sistem informasi genetik (DNA dan RNA), untuk membran sel (fosfolipid), dan fosfoprotein (Lambers et al., 2008). Berat 100 biji yang dihasilkan dipengaruhi oleh jumlah cabang produktif dan jumlah polong tanaman (Ohorella, 2011).

Pemberian pupuk organik berpengaruh nyata terhadap hasil biji kacang hijau. Berat biji tertinggi dihasilkan pada pemberian pupuk organik dosis 20 ton $\mathrm{ha}^{-1}$ (14,48 gram /tanaman) yang tidak berbeda nyata dengan perlakuan dosis 5, 10 dan 15 ton ha ${ }^{-1}$. Berat biji terendah dihasilkan pada perlakuan tanpa pupuk organik (Table 2.). Berat biji tanaman kacang hijau ditentukan oleh faktor genetik, praktek agronomi yang baik, dan kondisi lingkungan (Ali et al., 2010). Menurut Hidayat (2008), suplai fosfor dalam organ tanaman meningkatkan metabolisme dalam tanaman, terutama pada fase pengisian biji dapat meningkatkan berat biji.

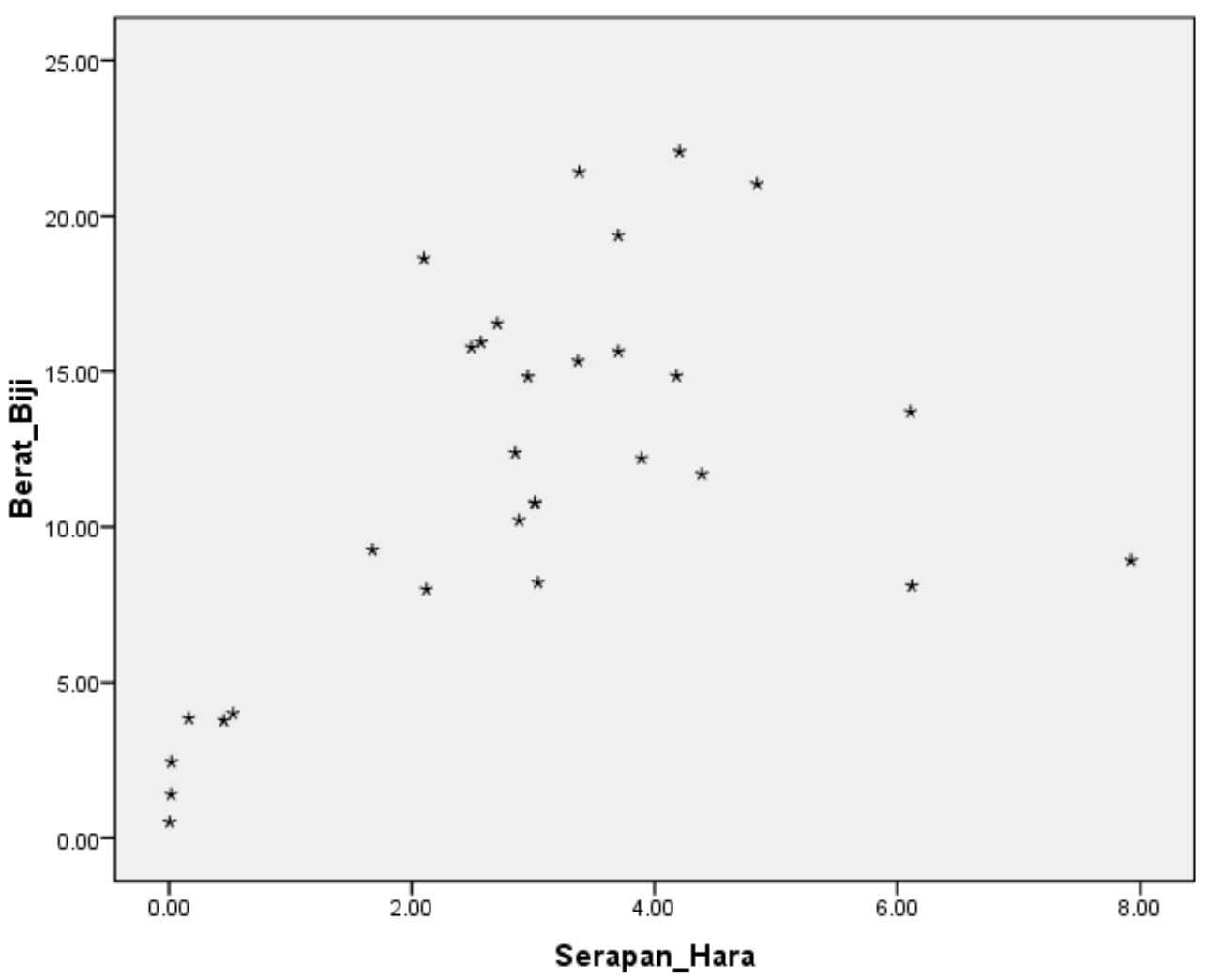

Figure 2. Correlation test of seed weight and nutrition absorbtion

Serangan pada fase pertumbuhan polong dan perkembangan biji menyebabkan polong dan biji kempis serta menyebabkan biji menjadi hitam (Bayu dan Tengkano, 2014). Serapan hara oleh tanaman berpengaruh pada berat hasil biji (Figure 2.). Konsentrasi suatu unsur hara dalam tanaman merupakan hasil interaksi semua faktor yang mempengaruhi penyerapan unsur tersebut dalam tanah. Hara fosfor $(\mathrm{P})$ berperan penting dalam proses fotosintesis, asimilasi dan respirasi (Liferdi, 2009). Serapan tertinggi hara P oleh tanaman ditunjukkan pada perlakuan pupuk organik dosis 20 ton ha ${ }^{-1}$ (4,34 g/tanaman), yang tidak berbeda nyata dengan dosis 5,10 dan 15 ton ha $^{-1}$. Serapan hara terendah tampak pada perlakuan tanpa pupuk organik (Table 2.). Menurut Afandi et al., (2015), pemberian bahan organik berupa kotoran ayam, kotoran sapi dan 
kompos meningkatkan serapan $\mathrm{P}$ tanaman secara nyata. Menurut Kumawat et al. (2009), pemberian pupuk $\mathrm{P}$ memperbaiki serapan dan translokasi hara N, P dan K pada fase reproduksi.

\section{KESIMPULAN DAN SARAN}

\section{Kesimpulan}

Pemberian pupuk organik dan kerapatan tanaman tidak berinteraksi terhadap pertumbuhan dan hasil biji kacang hijau. Tanggapan pertanaman kacang hijau populasi rapat (dua tanaman per lubang) dan populasi renggang (satu tanaman per lubang) terhadap pupuk organik relatif sama. Peningkatan hasil terjadi bila tanaman dipupuk organik dibandingkan dengan tidak dipupuk. Pupuk organik untuk kacang hijau cukup 5 ton ha $^{-1}$ dengan hasil mencapai sekitar 1,3 - 1,4 ton $\mathrm{ha}^{-1}$. Serapan P tanaman berkorelasi nyata dengan hasil biji.

\section{Saran}

Pengelolaan budiaya kacang hijau dapat dilakukan dengan penanaman satu tanaman per lubang tanam serta penggunaan pupuk organik (kandang ayam) sebesar 5 ton ha ${ }^{-1}$.

\section{DAFTAR PUSTAKA}

Afandi, F. N., Siswanto, B., \& Nuraini, Y. 2015. Pengaruh Pemberian Berbagai Jenis Bahan Organik Terhadap Sifat Kimia Tanah Pada Pertumbuhan Dan Produksi Tanaman Ubi Jalar Di Entisol Ngrangkah Pawon, Kediri. Jurnal Tanah Dan Sumberdaya Lahan, 2(2), 237-244. Retrieved from http://jtsl.ub.ac.id/index.php/jtsl/article/view/1 34

Ahmad, R., Mahmood, I., Kamal, J., \& Bukhari, S. A. H. 2004. Growth and Yield Response of Three Mungbean ( Vigna radiata L .) Cultivars to Varying Seeding Rates, 03(06), 538-540. Retrieved from http://www.fspublishers.org/published_papers /69867_..pdf

Ali, M. A., Abbas, G., Mohy-ud-Din, Q., Ullah, K., Abbas, G., \& Aslam, M. 2010. Response of Mungbean (Vigna radiata) to phosphatic fertilizer under arid climate. Journal of Animal and Plant Sciences, 20(2), 83-86. Retrieved from http://thejaps.org.pk/docs/20-22010/Abbas-et-al.pdf
Asaduzzaman, M., Karim, M. F., Ullah, M. J., \& Mirza, H. 2008. Response of Mungbean ( Vigna radiata L .) To Nitrogen and Irrigation Management. American-Eurasian Journal of Scientific Research, 3(1), 40-43. Retrieved from

https://www.researchgate.net/profile/Md_Asa duzzaman7/publication/265965885_Response _of_mungbean_Vigna_radiata_L_to_integrate d_nitrogen_and_irrigation_managements/link s/54220ca70cf238c6ea6784c4/Response-ofmungbean-Vigna-radiata-L-to-integratednitrogen-an

Badan Pusat Statistik, [BPS]. 2015. Produksi Kacang Hijau Menurut Provinsi (ton), 19932015. Retrieved September 8, 2018, from https://www.bps.go.id/dynamictable/2015/09/ 09/877/produksi-kacang-hijau-menurutprovinsi-ton-1993-2015.html

Bayu, M. S. Y. I., \& Tengkano, W. 2014. Endemik Kepik Hijau Pucat, Piezodorus hybneri Gmelin (Hemiptera: Pentatomidae) Dan Pengendaliannya. Buletin Palawija, 28(0), 73-83. https://doi.org/10.21082/BULPA.V0N28.201 4.P73-83

Bunyamin, Z., \& Awaluddin. 2013. Pengaruh Populasi Tanaman Terhadap Pertumbuhan Dan Hasil Jagung Semi ( Baby Corn ). In Seminar Nasional Serealia (pp. 214-219). Retrieved from http://balitsereal.litbang.pertanian.go.id/wpcontent/uploads/2016/12/3bd13.pdf

Choudhary, H. R., Sharma, O. P., Yadav, L. R., \& Choudhary, G. L. 2011. Effect of organic sources and chemical fertilizers on productivity of mungbean. Journal of Food Legumes, 24(4), 324-326. Retrieved from http://www.isprd.in/pdf/journal_final_jfl24_4. pdf

Hardjoloekito, A. J. H. S. 2009. Pengaruh Pengapuran dan Pemupukan $\mathrm{P}$ terhadap Pertumbuhan dan Hasil Tanaman Kedelai (Glycine max, L.) pada Tanah Latosol. MEDIA SOERJO, 5(2), 31-49. Retrieved from https://unsoer.ac.id/wpcontent/uploads/2018/02/3.Hari-Soeseno.pdf

Hidayat, N. 2008. Pertumbuhan dan Produksi Kacang Tanah (Arachis hypogea L.) Varietas Lokal Madura Pada Berbagai Jarak Tanam dan Pupuk Fosfor. Agrovivor, 1(1), 55-64. Retrieved from http://kompetensi.trunojoyo.ac.id/agrovigor/ar 
ticle/viewFile/232/214

Hossain, M. S., Hossain, A., Sarkar, M. A. R., Jahiruddin, M., Teixeira da Silva, J. A., \& Hossain, M. I. 2016. Productivity and soil fertility of the rice-wheat system in the High Ganges River Floodplain of Bangladesh is influenced by the inclusion of legumes and manure. Agriculture, Ecosystems \& Environment, $\quad 218, \quad 40-52$. https://doi.org/10.1016/J.AGEE.2015.11.017

Jahan, S., \& Hamid, A. 2004. Effect of Population Density and Planting Configuration on Dry Matter Allocation and Yield in Mungbean (Vigna radiata (L.) Wilczek). Pakistan Journal of Biological Sciences, 7(9), 1493-1498. Retrieved from http://docsdrive.com/pdfs/ansinet/pjbs/2004/1 493-1498.pdf

Kresnatita, S., Koesriharti, \& Santoso, M. 2013. Pengaruh Rabuk Organik terhadap Pertumbuhan dan Hasil Tanaman Jagung Manis. Igtj.Ub.Ac.Id, 2(1), 8-17. Retrieved from

http://igtj.ub.ac.id/index.php/igtj/article/view/ 108

Kumawat, N., Kumar, R., \& Sharma, O. P. 2009. Nutrient Uptake and Yield of Mungbean Vigna radiata (L.) Wilczek as Influenced by Organic Manures, PSB and Phosphorus Fertilization. Environment \& Ecology, 27(4B), 2002-2005. Retrieved from https://www.researchgate.net/profile/Narendr a_Kumawat/publication/258641717_Nutrient _Uptake_and_Yield_of_Mungbean_Vigna_ra diata_LWilczek_as_Influenced_by_Organic_ Manures_PSB_and_Phosphorus_Fertilization/ links/02e7e528c567001def000000.pdf

Lambers, H., Chapin, F. S., \& Pons, T. L. 2008. Plant Physiological Ecology. New York, NY: Springer New York. https://doi.org/10.1007/978-0-387-78341-3

Liferdi, L. 2009. Analisis Jaringan Daun sebagai Alat untuk Menentukan Status Hara Fosfor pada Tanaman Manggis. Junal Hortikultura, 19(3), 324-333. Retrieved from http://hortikultura.litbang.pertanian.go.id/jurn al_pdf/193/liferdi_analisis_manggis.pdf
Melati, M., Asiah, A., \& Rianawati, D. 2008. Aplikasi Pupuk Organik dan Residunya untuk Produksi Kedelai Panen Muda. Jurnal Agronomi Indonesia (Indonesian Journal of Agronomy), $36(3)$ https://doi.org/10.24831/JAI.V36I3.1378

Ohorella, Z. 2011. Respon Pertumbuhan dan Produksi Tanaman Kedelai pada Sistem Olah Tanah yang Berbeda. Jurnal Agronomika, l(2), 92-98. Retrieved from http://jurnal.lipi.go.id/publikasi.cgi?tampilpub likasi\&1328740247\&Indonesia\&1\&1326362 280

Purwono, \& Hartono, R. 2005. Kacang Hijau. Jakarta: Penebar Swadaya. Retrieved from https://books.google.co.id/books?id=1vqDykp qLzYC\&printsec $=$ frontcover\&hl $=\mathrm{id} \&$ source $=$ gbs_ge_summary_r\&cad $=0 \# \mathrm{v}=$ onepage $\& \mathrm{q} \& \mathrm{f}$ $=$ false

Rachmadhani, N. W., Koesriharti, K., \& Santoso, M. 2014. Pengaruh Pupuk Organik dan Pupuk Anorganik terhadap Pertumbuhan dan Hasil Tanaman Buncis Tegak (Phaseolus vulgaris L.). Jurnal Produksi Tanaman, 2(6), 443-452. https://doi.org/10.21176/PROTAN.V2I6.129

Shukla, L., \& Tyagi, S. P. 2009. Effect of integrated application of organic manures on soil parameters and growth of mungbean ( Vigna radiata ). Indian Journal of Agricultural Sciences, 79(3), 174-177. Retrieved from http://krishikosh.egranth.ac.in/bitstream/1/353 30/1/microbiology 2.pdf

Susanti, H., Aziz, S. A., \& Melati, M. 2008. Produksi Biomassa dan Bahan Bioaktif Kolesom (Talinum triangulare (Jacq.) Willd) dari Berbagai Asal Bibit dan Dosis Pupuk Kandang Ayam. Jurnal Agronomi Indonesia (Indonesian Journal of Agronomy), 36(1), 4855. https://doi.org/10.24831/JAI.V36I1.1346

Suwahyono, U. 2011. Petunujk Praktis Penggunaan Pupuk Organik Secara Efektif \&amp; Efisien. Jakarta: Penebar Swadaya. Retrieved from https://books.google.co.id/books?id=1ugCgAAQBAJ\&printsec $=$ frontcover\&hl=id\&s ource=gbs_ge_summary_r $\&$ cad $=0 \# v=$ onepag $\mathrm{e} \& \mathrm{q} \& \mathrm{f}=\mathrm{false}$ 